\title{
Цвет в архитектуре деревянных храмов XVII-XVIII веков
}

\author{
А.Б.Бодэ, НИИТИАГ, Москва
}

Использование цвета в традиционном деревянном зодчестве представляет собой практически неизученный вопрос. Традиционные деревянные бревенчатые храмы представляются нам практически монохромными. Однако имеется немало свидетельств о том, что в архитектуре деревянных храмов XVII-XVIII веков использовались цветная покраска и росписи: это архитектурные фоны северорусских икон, миниатюры и аксонометрические планы, на которых деревянные храмы и иные сооружения изображены с крашеными кровлями, а иногда и с крашеными стенами или деталями. В статье систематизируются и анализируются данные о покраске деревянных построек. Выявляются определённые закономерности в использовании цвета и наиболее распространённые цветовые композиции. В качестве основных выводов можно отметить, что покраска тёсовых и лемеховых кровель деревянных храмов была достаточно распространена. Иногда она выполнялась в один цвет, иногда в два или даже в три цвета. На крышах многих изображённых зданий устойчиво повторяется сочетание красного внизу и зелёного (темно-зелёного) вверху. Хотя при этом многие традиционные деревянные постройки и не имели в своём архитектурном облике каких-либо цветовых решений. Данные старинных изображений сопоставляются с материалами натурных обследований памятников деревянного зодчества и фотографиями начала и середины XX века, когда покраска на старых зданиях ещё прочитывалась достаточно отчётливо. Совокупные сведения о покраске деревянных храмов XVI-XVIII веков и XIX - начала XX века позволяют сделать вывод о том, что цвет играл значительную роль в формировании архитектурного облика традиционных русских деревянных церквей.

Ключевые слова: деревянное зодчество, цвет в традиционной архитектуре, реконструкции первоначального облика.

\section{Color in the Architecture of Wooden Temples of the XVII- XVIII Centuries}

\section{A.B.Bode, NIITIAG, Moscow}

The use of color in traditional wooden architecture is a practically unexplored issue. Traditional wooden log temples seem to us almost monochrome. However, there is alot of evidence that the wooden temples of the XVII-XVIII centuries used color painting in the architecture: these are the architectural backgrounds of the North Russian icons, miniatures and axonometric plans, on which wooden temples and other structures are depicted with painted roofs and sometimes with painted walls or parts. The article systematizes and analyzes the data on the painting of wooden buildings. Certain patterns in the use of color and the most common color compositions are identified. As the main conclusion it can be noted that the painting of plank and plowshare roofs of wooden temples was quite common. Sometimes it was performed in one color, sometimes in two or even three colors. On the roofs of many depicted buildings the combination of red below and green (dark green) above is consistently repeated. Although at the same time many traditional wooden buildings did not have any color solutions in their architectural appearance. The data of ancient images is compared with the materials of field surveys of wooden architecture monuments and photographs of the beginning and middle of the XX century, when painting on old buildings was still quite clear. The cumulative information on the painting of wooden temples of the XVI-XVIII centuries and the XIX-early XX centuries allows us to conclude that color played a significant role in shaping the architectural appearance of traditional Russian wooden churches.

Keywords: wooden architecture, color in traditional architecture, reconstruction of the original appearance.

Традиционные деревянные бревенчатые храмы с необшитыми бревенчатыми стенами и серебристыми от времени кровлями монохромны. Именно такими они предстают нам в музеях под открытым небом и на своих исторических местах. Использование цвета в деревянной архитектуре устойчиво соотносится с периодом XIX - начала XX века, когда старые храмы массово ремонтировались, получая обшивку стен и металлические кровли, а новые постройки возводились соответственно сразу под обшивку. Дощатые обшивки практически всегда окрашивались, детали нередко приобретали многоцветную покраску. Об этом свидетельствуют многочисленные следы сильно осыпавшейся, но достаточно явно читающейся краски под карнизами, свесами крыш и в укрытых от атмосферного воздействия местах. Окрашивались и кровли, причём не только металлические, но и деревянные. Это мы определяем по едва сохранившимся частицам краски на кровельном тёсе и лемехе и по старым фотографиям.

Использование цвета в деревянной церковной архитектуре исследовано мало, поскольку при изучении деревянного зодчества обычно в первую очередь внимание обращалось 
на объекты, построенные в XVII-XVIII веках. Архитектура поздних деревянных церквей и стилистические ремонты XIX - начала XX века до недавнего времени вообще практически не изучались. В реставрационной практике советского времени, нацеленной на воссоздание первоначального, во всяком случае, дообшивочного облика, к позднейшим наслоениям относились пренебрежительно, считая их не заслуживающими интереса и сохранения. Соответственно обшивка и позднейший декор со следами покраски при целостных реставрациях исчезали бесследно и даже не фиксировались. В последние десятилетия XX века и в начале нынешнего столетия подходы к реставрации несколько изменились. Наряду с целостными реставрациями стали реализовываться проекты с сохранением обшивок или фрагментарные решения. Появились научно-исследовательские работы по архитектуре деревянных церквей XIX века. Однако всё равно цветовые решения в композициях фасадов деревянных храмов пока не привлекли специального внимания.

Наряду с данными о покраске деревянных церквей XIX века имеется немало свидетельств о том, что в архитектуре более ранних традиционных деревянных храмов XVII-XVIII веков также использовались цветная покраска и росписи.

Значительный круг исторических источников составляют архитектурные фоны северорусских икон, миниатюры и аксонометрические планы. Изображённые на них деревянные здания имеют прорисовку серым или охристо-коричневым цветом. Подобные строения нередко соседствуют с каменными зданиями, стены которых выглядят гладкими побеленными. Среди изображённых построек мы видим самые разные типы зданий - церкви, часовни, жилые дома, монастырские кельи, оборонительные башни и стены. Конкретные известные нам объекты на разных иконах изображены немного по-разному. Бывает, что одна и та же церковь при сходных общих формах показана то с неокрашенной тёсовой кровлей, то с крашеной, причём в разные цвета. Некоторые изображения обобщённые и даже схематичные. В целом надо признать, что архитектурные фоны икон и старинные миниатюры при всей своей разнородности представляют собой значительный материал для исследований, отображающий традиционное деревянное строительство в самых разных местах Русского Севера.

Старинные изображения северорусских монастырей и погостов обстоятельно изучены М.И. Мильчиком, посвятившим этой теме многолетние исследования. Материалы были опубликованы в разных статьях и недавно сведены в одну книгу с цветными иллюстрациями [1]. Последнее особенно ценно тем, что, представляя столь значительный ряд репродукций, книга по сути открывает новый взгляд на использовании цветной покраски в традиционном деревянном зодчестве. Правда, М.И. Мильчик, детально анализируя изображения и сопоставляя их с реально существовавшими или существующими объектами, на цветовых решениях внимания не заостряет.

Самое важное то, что изображения на иконах являются единственными источником, который показывает северорус- ские деревянные храмы в своём первоначальном облике. Все старинные церкви и часовни дошли до нас в перестроенном или ремонтном виде, со многими частями, безвозвратно утраченными, тогда как на иконах мы видим те кровли, галереи, крыльца, которые были на ранних строительных этапах.

Рассмотрим сначала монохромные изображения. Прорисовка коричневатым цветом бревенчатых стен, окон, крылец и иных деталей не оставляет сомнений, что перед нами срубные постройки с тёсовыми кровлями, не имеющие какой-либо покраски.

К подобным объектам относится Александро-Ошевенский монастырь, изображённый на многочисленных иконах XVIIXIX веков [2, с. 333-346]. На большинстве икон деревянный монастырский комплекс, состоящий из двух шатровых храмов, колокольни, келий, подсобных построек и ограды, изображён монохромным (рис. 1). Есть варианты изображений этого монастыря с ограниченным использованием цвета, но мы остановимся на этом отдельно.

Таков же Артемиев-Веркольский монастырь, включающий два храма и сопутствующие здания [3, с. 487-496]. Изображения этого монастыря, известные нам по иконам XVII-XVIII веков, отличаются тем, что на всех иконах они монохромны и при этом имеют достаточно подробную прорисовку деталей. Исключение составляют только главки, иногда окрашивавшиеся в тёмный цвет, приближенный к чёрному [1, с. 247, 250].

Можно упомянуть и план города Олонца XVII века, на котором все деревянные строения показаны монохромно [1, с. $342,343]$. При этом однако подкрашены цветом трава и река,

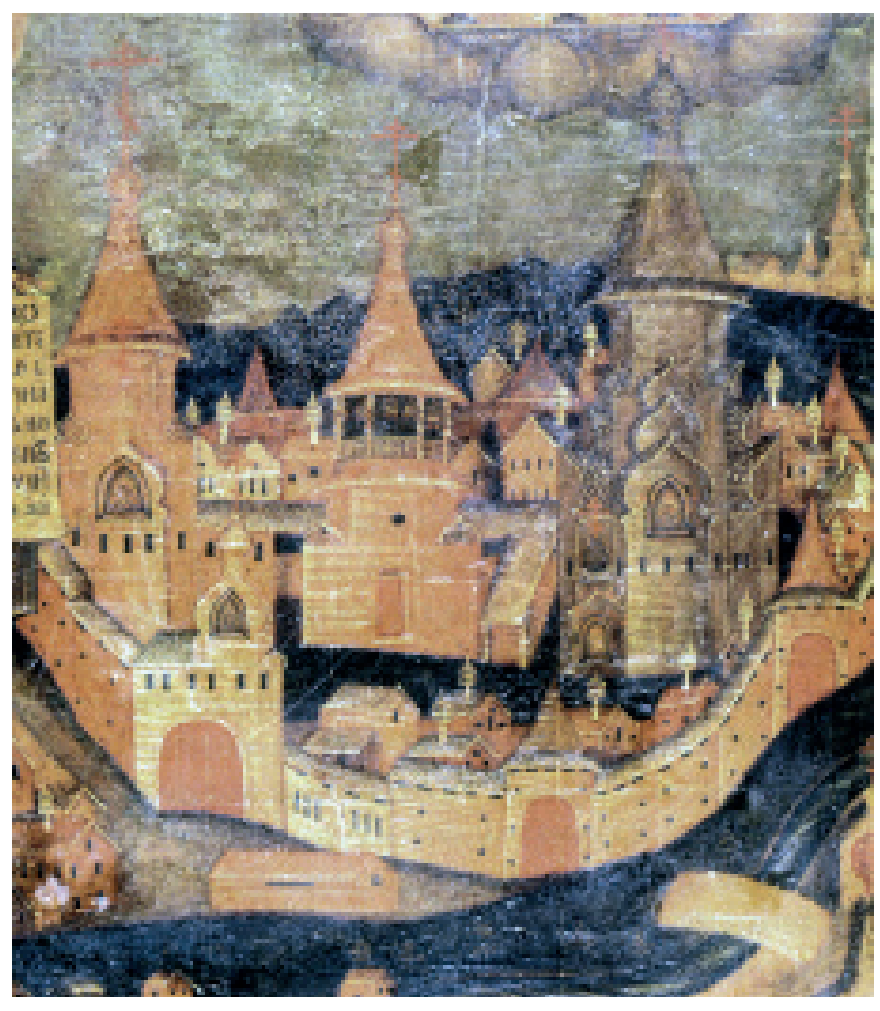

Рис. 1. Александро-Ошевенский монастырь на иконе XVII века 
что наводит на мысль, что деревянные здания действительно были неокрашенными.

Каргопольская крепость, судя по изображению на иконе Бориса и Глеба начала XVIII века' ${ }^{1}$ представляла собой полностью деревянное сооружение, внутри которого располагались деревянные строения и одна каменная церковь (рис. 2). История и архитектура каргопольской крепости достаточно хорошо изучена, и достоверность изображённых на иконе построек подтверждается сопоставлениями с данными исторических источников и планировочной ситуацией, сохранившейся в натуре [4, с. 60-76]. В изображении присутствуют отдельные цветные элементы, которые мы рассмотрим чуть позже, но в целом облик города составляют деревянные некрашеные здания и сооружения.

Можно привести ещё примеры изображений деревянных монохромных построек, присутствующих в большом числе в Атласе Архангельской губернии 1797 года [5, с. 768-769]. Это панорамы Соловецкого монастыря, Николо-Карельского монастыря и упомянутого выше Артемиев-Веркольского монастыря, на которых деревянные постройки чётко отличаются от каменныхи имеют прорисовку коричневым цветом без какой-либо цветной покраски [1, с. 34, 35, 249]. Достаточно реалистично изображены деревянные стены и башни Тихвинского Успенского монастыря на миниатюре из рукописи «Сказание об иконе Тихвинской Богоматери» конца XVII века [1, с. 148]. Бревенчатые стены окрашены охрой, а тёсовые кровли - серым. На некоторых изображениях Тихвинского монастыря второго извода деревянные сооружения также показаны неокрашенными [5, с. 173, 174].

${ }^{1}$ Икона «Борис и Глеб с изобращением горящего Каргополя». Начало XVIII века. Каргопольский историко-архитектурный и художественный музей. Инв. № КП 8653.

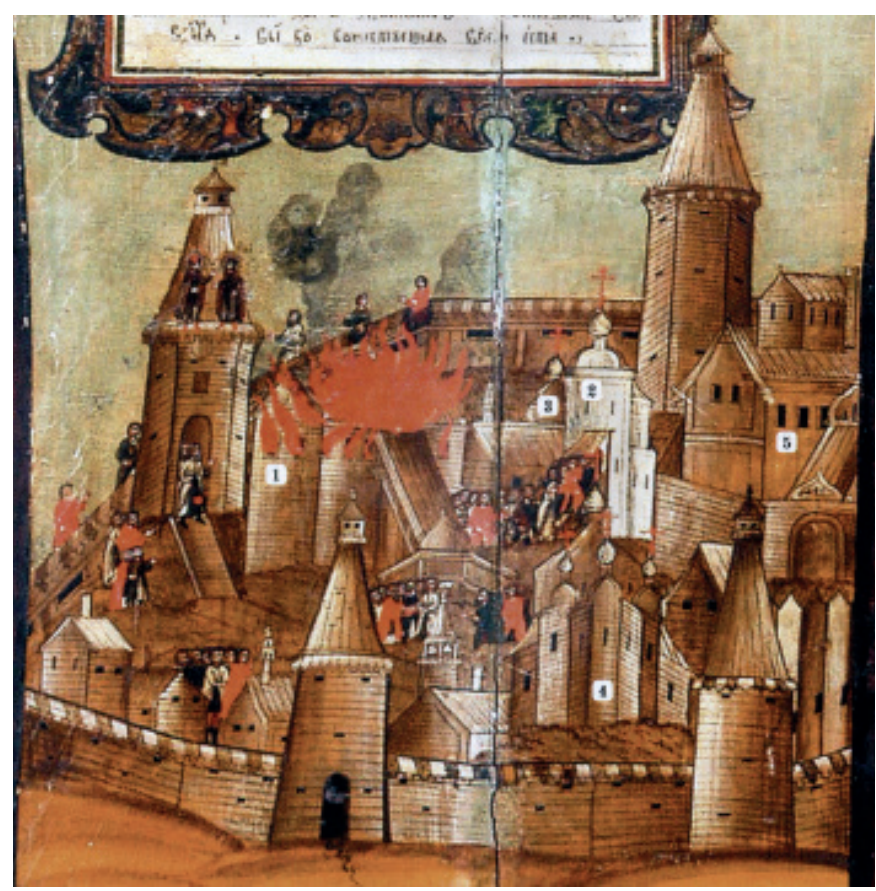

Рис. 2. Икона свв. Бориса и Глеба с изображением Каргопольской крепости. Начало XVIII века
Далее обратим внимание на значительное число изображений, где бревенчатые стены зданий сочетаются с кровлями, окрашенными в один цвет.

Таково изображение на аксонометрическом плане 1695 года Николо-Разважского монастыря под Новгородом, где стены, башни и внутримонастырские здания показаны деревянными бревенчатыми, а кровли окрашены зелёным цветом [6]. На иконописных изображениях конца XVII - начала XVIII века Антониев-Дымского монастыря кровли всех деревянных зданий, включая церковь, колокольню, кельи и ограду, окрашены тёмно-синим или тёмно-зелёным почти черным цветом [1, с. 268-269; 7, с. 141-154]. Среди многочисленных иконописных изображений комплекса Александро-Ошевенского монастыря мы также находим примеры покраски шатров двух церквей, колокольни и окружающих строений красным или зелёным цветом [1, с. 233].

Есть несколько примеров изображений комплексов каменных и деревянных построек с единообразно окрашенными кровлями. Это виды Соловецкого монастыря на лицевых рукописях рубежа XVI-XVII веков и на многих иконах начала XVII-XVIII веков, на которых все кровли, включая деревянные кровли стен и башен, окрашены красным цветом [1, с. 41, 43, $61,63,67]$. Такие же изображения, где все деревянные и каменные здания покрыты одинаковыми, но уже зелёными или красными крышами, имеются и в иконографии Тихвинского монастыря XVIII века [1, с. 149, 150, 172].

Также мы имеем значительный ряд изображений, где кровли окрашены в два цвета. Рассмотрим, какие это были цвета и как они сочетались друг с другом.

На одной из икон Александра Ошевенского последней четверти XVII века шатры церквей покрашены красным цветом, а венчающие их главы - зелёным [1, с. 222]. Такое же сочетание красного шатра на крещатой бочке с тёмно-зелёными главами мы находим на иконе праведного Прокопия Устьянского середины XVIII века [1, с. 261]. Хотя на других иконах праведного Прокопия эта же церковь изображена с полностью красными или тёмно-зелёными кровлями [1, с. 260, 261].

Богатый для подобного рассмотрения материал дают изображения Тихвинского монастыря. На одной из миниатюр из рукописи «Сказание об иконе Тихвинской Богоматери» конца XVII века шатры башен изображены разноцветными, причём в нескольких разных вариантах [1, с. 150]. Разными цветами покрашены полицы, нижняя и верхняя половины шатра. Для покраски использованы охра, красная, коричневая и зелёная и краски. Сочетание цветов на разных башнях самое разное, и никакие закономерности здесь не просматриваются. На изображениях Тихвинского монастыря второго извода XVIII - начала XIX века наблюдается сочетание красного и зелёного цветов [1, c. 172-175]. На одной из миниатюр красные полицы сочетаются с зелёным шатром, как мы отмечали ранее. Но на других изображениях то красные полицы сочетаются с охрой шатра, то зелёные полицы с красным верхом, то полностью окрашенные охрой шатры с полицами сочетаются с зелёной вышкой. 
Обратим внимание и на иконописные изображения Ниловой пустыни на иконах преп. Нила Столбенского третьей четверти XVII века [1, с. 291-293]. Перед нами две ярусные церкви и колокольня. Крыши нижних ярусов окрашены тёмносиней или тёмно-зелёной (почти чёрной) красками. Крыши верхних ярусов - красные.

Сочетание красного и зелёного цветов в покраске кровель мы встречаем ещё на одном неожиданном для нас объекте на русской часовне 1820-х годов в Форт-Россе в Калифорнии. Цветное изображение этой часовни имеется на акварели И.Г. Вознесенского 1841 года, хранящейся в фондах Института археологии и этнографии РАН) Над простой вальмовой красной крышей часовни возвышаются два барабана с зелёными куполами. Эта постройка достаточно поздняя и очень простая по архитектуре, но и она отчётливо отображает цветовую композицию, наблюдаемую нами на самых разных объектах.

Аналогичное расположение красной покраски внизу и зелёной (тёмно-зелёной или тёмно-синей) наверху мы встречаем и на старинных изображениях каменных храмов. На нескольких иконах Богоматери Молебной с предстоящими преп. Зосимой и Савватием середины XVI века изображён каменный монастырский храм с ярусами кокошников. Нижние кокошники окрашены красным, верхние кокошники и главы - зелёным [1, c. 38]. Также на одной из икон преп. Зосимы и Савватия конца XVII века шатёр показан красным, а главы - серо-синие [1, с. 69]. Другая икона преп. Зосимы и Савватия с 22-мя клеймами со сценами их жития последней четверти XVI века представляет собор очень схематично - с шатровым верхом, не соответствующим реальности. Крыша алтаря окрашена красным, шатёр - чёрным, а стоящие рядом кельи имеют тёсовую чёрную кровлю [1, с. 40]. В Атласе Архангельской губернии 1797 года Преображенский соловецкий собор показан с кровлями, уже изменёнными позднейшими перестройками [5, с. 768-769]. И здесь мы также видим, что четырёхскатная кровля собора окрашена красным, главы - зелёным.

Еще обратим внимание на немногочисленные примеры изображений кровель, окрашенных полосами. На одной из икон преп. Зосимы и Савватия с видом Соловецкого монастыря все монастырские постройки показаны с крышами, окрашенными крупными полосами красного и тёмно-зелёного (или чёрного) цвета [1, с. 66]. Скорее всего крыши монастырских зданий такими никогда не были, поскольку на всех остальных изображениях монастыря кровли показаны иными, окрашенными в разные цвета. Видимо, это фантазия художника, возникшая однако не на пустом месте. Такая покраска была, о чём свидетельствует упоминаемое нами выше изображение Каргопольской крепости на иконе Бориса и Глеба. На нём покрытие боевого хода и полицы нескольких башен показаны окрашенными такими же крупными полосами чёрного и белого цвета.

Некоторые старинные изображения наводят на мысль о том, что могли быть окрашенными не только кровли, но и стены. На иконах преп. Нила Столбенского одна церковь нарисована бревенчатой с характерной прорисовкой и окрашена корич- невым цветом. На углах срубов второй трёхъярусной церкви и колокольни мы видим вертикально прибитые доски, а стены их окрашены той же красной краской, что и кровли [1 с. 291-293]. Похоже, что эти два строения изображены с обшивкой, которая окрашена. Нечто подобное мы видим на одном из изображений Ошевенского монастыря. Одна церковь окрашена коричневым цветом, другая церковь и колокольня окрашены красным [1, с. 233]. Правда, здесь нет различия в прорисовке, которое указало бы на открытый сруб или наличие обшивки. Чем объяснить это различие в изображении? Возможно, это попытка изобразить обшитое здание, но не исключено - просто художественная манера автора. Других изображений, где можно было бы увидеть старинное здание в обшивке и определить её цвет, мы не находим.

Также нельзя не упомянуть о крайне малочисленных известных примерах раскраски бревенчатых стен. Их всего два. Это Покровская церковь 1695 года Шадринского погоста и Ильинская церковь 1756 года в деревне Возгрецовская (село Ростовское) близ Вельска [8, с. 20-28]. На этих церквях наружная раскраска стен геометрическим орнаментом в виде руста известны по рисункам В.В. Суслова конца XIX века. Рас-

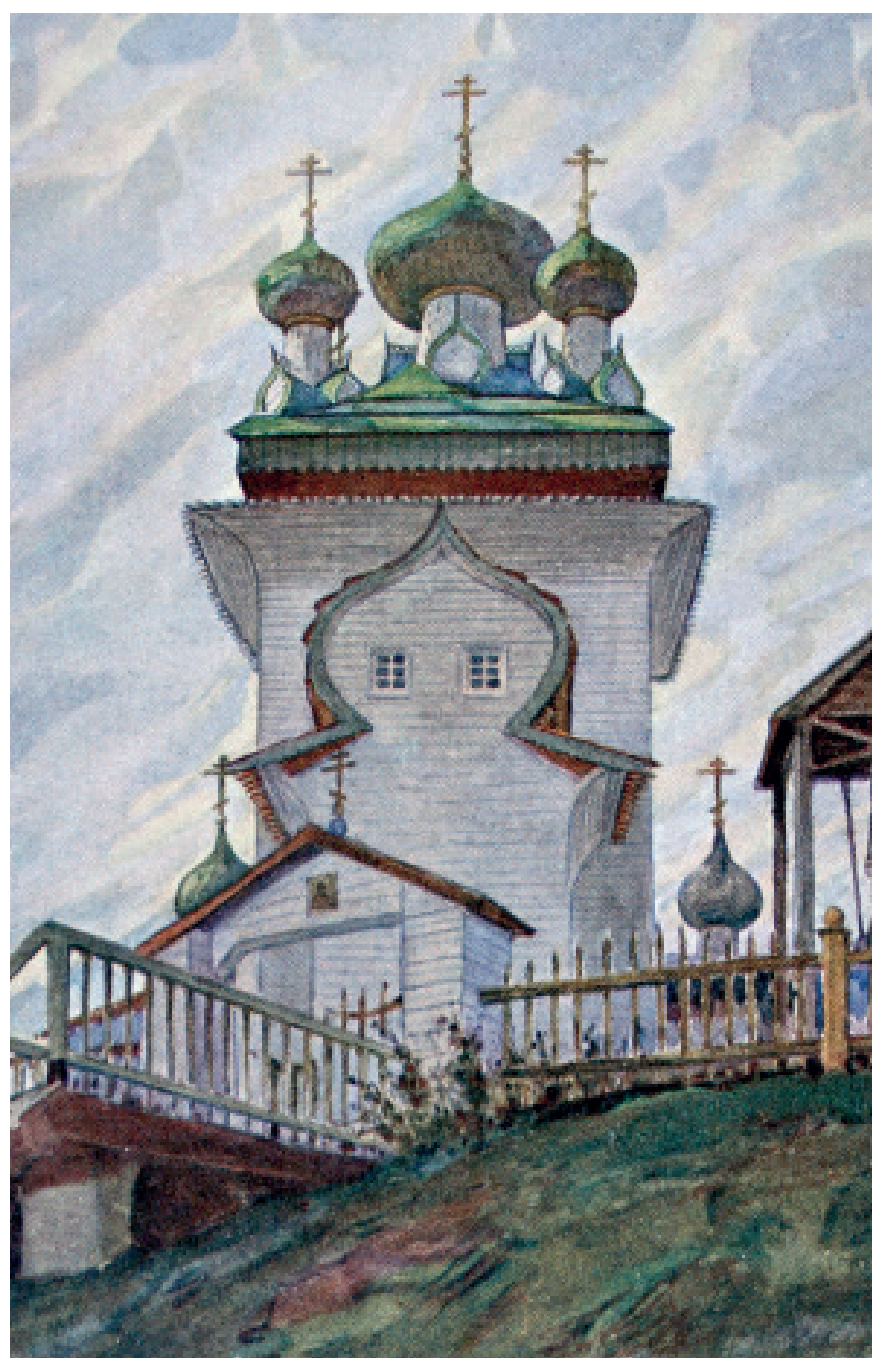

Рис. 3. Вознесенская церковь 1669 года в селе Кушерецком. Акварель В. Плотникова начала ХХ века 
краска, по-видимому, была выполнена по гладко отёсанным бревнам, хотя не исключено, что и по обшивке. Она создавала очень непривычный для деревянного здания облик, явно перекликающийся с особенностями каменного зодчества конца XVII века. Подобную раскраску стен имели надвратная церковь Иоанна Предтечи (1693-1699) в Троице-Сергиевой лавре [9, с. 120-122], Лопухинская башня Ново-Девичьего монастыря в Москве [10, с. 160-170] и другие постройки.

Итак, по результатам рассмотрения приведённых примеров можно сделать некоторые заключения относительно использования цвета в архитектуре деревянных храмов XVII-XVIII веков:

1) многие традиционные деревянные постройки не имели в своём архитектурном облике каких-либо цветовых решений. Колорит здания определяли необшитые бревенчатые стены и неокрашенные тёсовые кровли;

2) вместе с тем покраска тёсовых и лемеховых кровель была достаточно распространена. Иногда она выполнялась в один цвет, иногда в два или даже в три цвета;

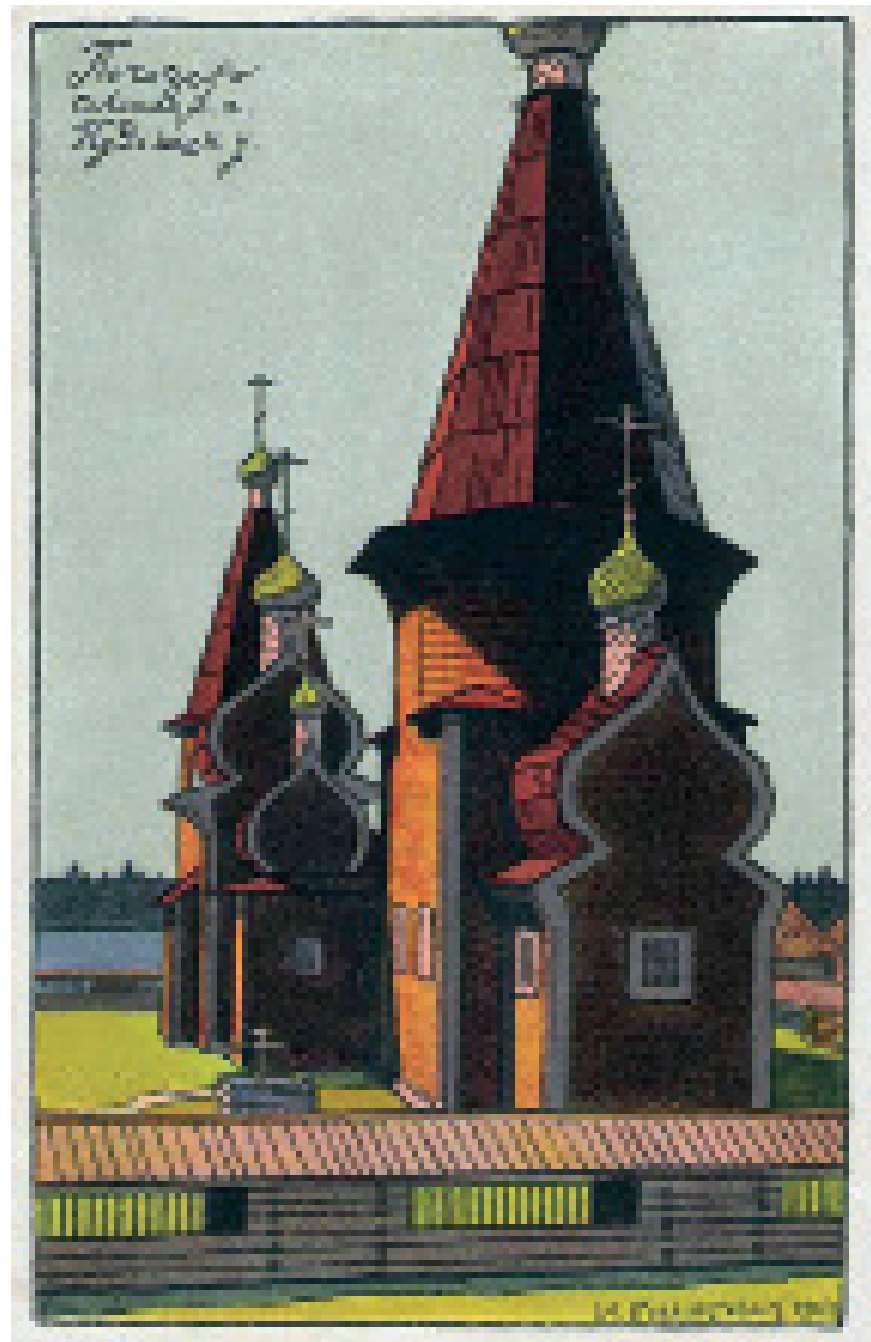

PUс. 4. Храмовый комплекс в Почозерском погосте (XVIII век). Рис. И. Билибина
3) для покраски кровель использовались красная, зелёная и чёрная краски. Возможно, это была не чёрная краска, а приближенная к ней тёмно-зелёная или тёмно-синяя;

4) на крышах многих изображённых зданий устойчиво повторяется сочетание красного внизу и зелёного (тёмнозелёного) вверху, например, красные полицы и зелёный шатёр, красная крыша и зелёные главы.

Однако эти выводы, как мы прекрасно понимаем, основаны на материале, который нельзя считать полностью достоверным. Ответ на вопрос: насколько вообще достоверна покраска зданий на архитектурных фонах икон и старинных миниатюрах, - наверное, может быть такой: насколько правдоподобны изображения архитектурных форм, настолько и их покраска. Правдоподобность форм изображаемых объектов, как мы видим, различна. Например, постройки Соловецкого монастыря на одних иконах или миниатюрах изображены вполне реалистично, на других - условно или их изображение даже вымышлено. То есть и покраску зданий на старинных изображениях можно признать правдоподобной, но не всегда.

Действительно, одни и те же объекты предстают перед нами окрашенными совершенно по-разному. Художник, будучи не всегда воочию знаком с изображаемым объектом, допускал отступление от образца и различное цветовое решение, повидимому, основываясь на том, что он наблюдал на других зданиях. Исходя из этого надо полагать, что цветовая палитра старинных изображений не столько отражала реальную покраску того или иного объекта, но в значительно большей мере показывала приёмы покраски зданий, существовавшие в то время.

Для того, чтобы разобраться в правдоподобности покраски на старинных изображениях, обратимся к иным источникам. Это старые фотографии и рисунки, а также материалы натурных обследований объектов. Правда, они представляют уже совсем другой пласт в развитии деревянного зодчества, относящийся к периоду поновлений старинных храмов и нового строительства по образцовым проектам. Мы обращаемся к объектам этого периода в поисках аналогий с покраской более раннего времени, предполагая некую преемственность, несмотря на значительные изменения в архитектурном облике построек. Особенный интерес представляют обновлённые старинные храмы, в общем сохранившие свою первоначальную архитектуру и в силу этого, возможно, характер покраски.

Для нас бесценны цветные фотографии С.М. ПрокудинаГорского. Кроме того, деревянные храмы с ещё сохранившейся покраской можно увидеть на многих цветных фотографиях середины или второй половины XX века. Покраску стен и крыш мы видим и на чёрно-белых фотографиях, но далеко не всегда можем распознать цвет.

Многие церкви в конце XIX - начале XX века имели одинаковую, можно сказать, типовую покраску, включающую белые стены и зелёные кровли. Зелёная ярь-медянка действительно была наиболее распространённой краской для крыш. Таковы храмовые комплексы в селе Турчасово, Климентовская и Власьевская церкви в селе Тулгас, Ильинская церковь в селе 
Чухчерьма и другие. Церкви села Шуерецкое, запечатлённые на фотографии С.М. Прокудина-Горского (1909), тоже имеют зелёные крыши, но на одной из церквей - шатровой Никольской конца XVI века, перестраивавшейся в XVIII-XIX веках, мы видим красную крышу трапезной и прирубов основного храмового столпа. Зелёную покраску шатра и красную - полиц имела Преображенская церковь 1696 года в селе Пидьма, зафиксированная также на фотографии С.М. Прокудина-Горского. На акварели В. Плотникова начала XX века изображена Вознесенская церковь 1669 года в селе Кушерецком (рис. 3). Эта церковь имела кубоватое завершение, нижняя часть которого была окрашена красным, а верхняя вместе с главами - зелёным. Церкви Почозерского погоста, запечатлённые на рисунке И. Билибина, отличаются красной окраской всех крыш, в том числе бочек и шатров, и зелёной окраской глав (рис. 4). Такие же красные кровли мы замечаем на разных любительских фотографиях второй половины XX века церквей Ильинской в селе Вазенцы, Успенской в селе Варзуга, Входоиерусалимской в селе Верховье. Правда, на этих объектах не зафиксирована покраска глав. Но на фотографии

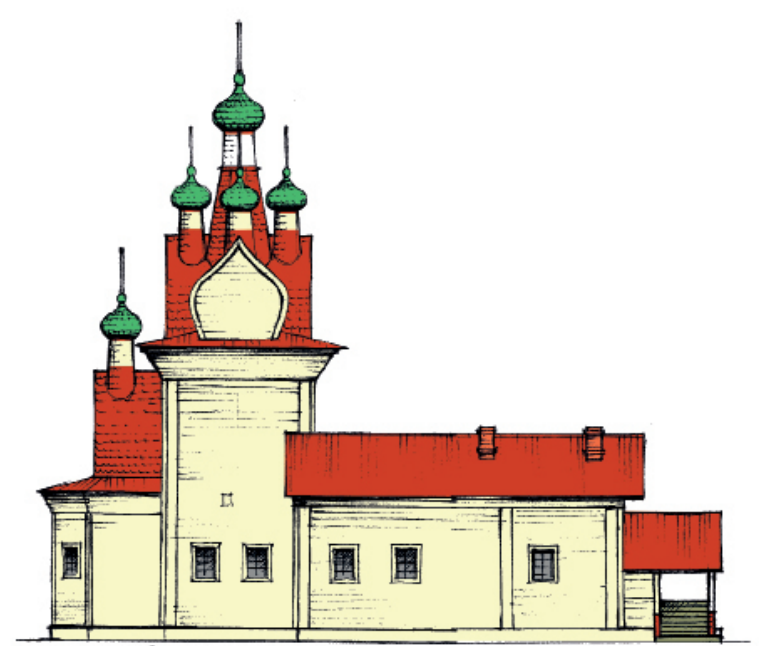

Рис. 5. Никольская церковь (1700) близ деревни Едома. Реконструкция цветового решения XIX века. Рисунок автора

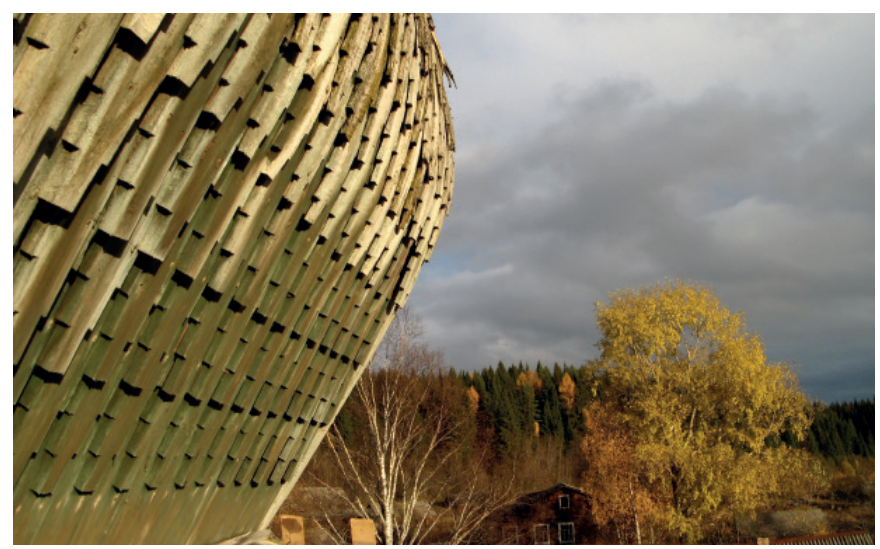

Рис. 6. Благовещенская церковь (1719) в деревне Пустынька. Следы покраски кровли зелёным цветом. Полицы были окрашены красным. Фотография В.И. Казакова
Никольской близ деревни Едома мы вновь видим красную покраску бочек и шатра и зелёную - глав, что воспроизведено на графической реконструкции (рис. 5).

Судя по фотографиям и рисункам XX века, церковные крыши предпочитали красить зелёным цветом, но вместе с тем обнаруживается немало примеров сочетания красной покраски внизу и зелёной наверху, иногда со значительным преобладанием красного, когда зелёными остаются только главы. Эти цветовые композиции в целом довольно чётко соответствуют рассмотренной ранее покраске крыш по изображениям XVII-XVIII веков.

И, наконец, обратимся к материалам натурных обследований сохранившихся объектов. Краска обычно сохраняется на северных стенах, не подверженных воздействию солнечного света, тогда как на южных стенах она исчезает бесследно. Следы покраски стен обычно остаются под карнизами. На кровлях обнаружить следы покраски труднее. Они сохраняются на вогнутых поверхностях кубов или бочек, а на прямых скатных кровлях стираются практически

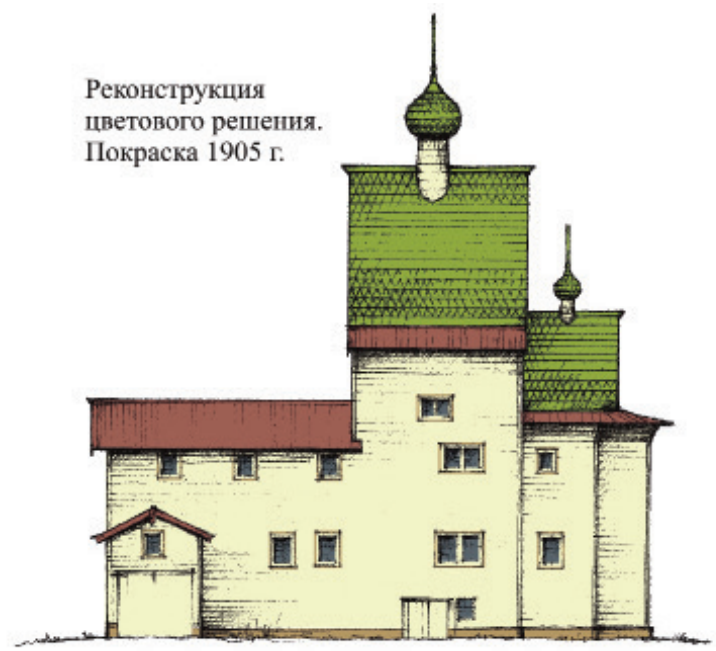

Pис. 7. Благовещенская церковь (1719) в деревне Пустынька Реконструкция цветового решения начала ХХ века. Рисунок автора

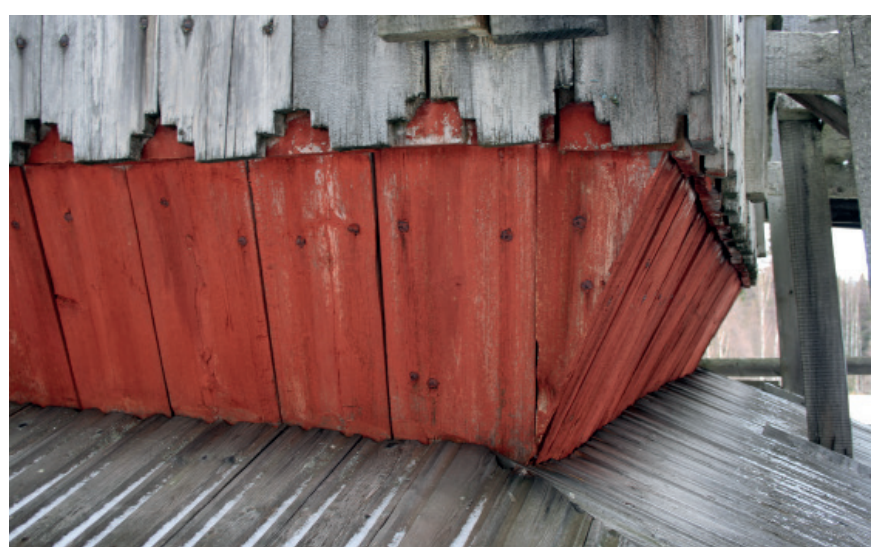

Рис. 8. Церковь Алексия Человека Божьего (1721) в урочище Куртяево. Покраска кубоватого завершения. Фото автора 
полностью, но иногда остаются в щелях и в виде подтёков на нижних слоях тёса.

Зелёная покраска бочек зафиксирована на Сретено-Михайловской церкви (1655) в Красной Ляге и церкви Рождества Христова (1745) в Большой Шалге. Покраска хорошо прочитывается на Благовещенской церкви (1719) в деревне Пустынька, отличающейся тем, что её основной сруб и алтарь завершаются бочками. Стены были побелены, полицы бочек были окрашены красным, а сами бочки - зелёным (рис. 6). На основе материалов натурного обследования мы имеем графическую реконструкцию цветового решения Благовещенской церкви (рис. 7). Покраска сохранилась на алтарной бочке Ильинской церкви (1798) на Водлозере. Эта бочка покрыта горизонтально уложенным тесом внахлёст. Нижние несколько досок покрашены красной краской, верхние - зелёной. Кубоватое завершение церкви Алексия Человека Божьего (1721) в урочище Куртяево также в нижней части окрашено красным, а в верхней - зелёным (рис. 8). На главах, сохранивших покрытие лемехом, мы находим следы покраски зелёным цветом. Это было замечено на Владимирской церкви в Подпорожье, Сретенской церкви в Заостровье, Петропавловской в Вирме и других. Покраски глав каким-либо иным цветом не обнаружено.

Результаты натурных обследований следов покраски деревянных церквей в совокупности с фотографиями XX века предоставляют достаточно достоверную информацию об использовании цвета в архитектуре деревянных храмов конца XIX - начала XX века. Цветовые композиции, использовавшиеся в это время, отчётливо повторяют покраску крыш деревянных храмов XVII-XVIII веков по изображениям на иконах и старинных миниатюрах и тем самым подтверждают их правдоподобность.

Таким образом, использование цвета в архитектуре деревянных храмов представляет собой традицию, бытовавшую в XVII-XVIII веках и не угасавшую в XIX - начале XX века. Продолжение изучения намеченной темы видится в более обширном обследовании сохранившихся памятников деревянного зодчества, поисках фотоматериалов и исторических графических источников, дающих сведения о покраске деревянных храмов.

\section{Лuтература}

1. Мильчик, М.И. Древнерусская иконография монастырей, храмов и городов XVI-XVIII веков: Статьи 1973-2017 / М.И. Мильчик. - СПб, 2017.

2. Мильчик, М.И. Северный деревянный монастырь на иконах XVII-XIXвв. / М.И. Мильчик // Памятники культуры. Новые открытия: Ежегодник. -Л., 1979.

3. Мильчик, М.И. Веркольский монастырь в иконографии XVII - XVIII вв. / М.И. Мильчик // Памятники культуры. Новые открытия: Ежегодник. - Л., 1987.

4. Мильчик, М.И. Каргопольская крепость. Этапы строительной истории / М.И Мильчик, А.Б. Бодэ // Архитектурное наследство. - 2008. - Вып. 49.

5. РГИА. Ф. 1350. 0п. 312. Д. 3.

6. РГАДА. Ф.192. Новгородская губ. Д.8 (План Николо-Разважского монастыря с окружающими дворами).
7. Мильчик, М.И. Иконография деревянного АнтониевДымского монастыря и его графическая реконструкция / М.И. Мильчик, Е.П. Варакин // Народное зодчество: сборник научных трудов. - Петрозаводск, 1992.

8. Шургин, И.Н. 0 наружных росписях деревянных церквей на Русском Севере в XVII - начале XVIII в. / И.Н. Шургин // Реставрация и исследование памятников культуры. - 2014. - Вып. 7.

9. Демидов, С.В. Исследование и реставрация полихромной покраски надвратного храма Рождества Иоанна Предтечи в Троице-Сергиевой лавре/ С.В. Демидов // Реставрация и исследование памятников культуры. - 2012. - Вып. 5.

10. Любимова, И.Д. Лопухинские палаты московского Богородице-Смоленского Новодевичьего монастыря: история и реставрация / И.Д. Любимова // Реставрация и исследование памятников культуры. - 2013. - Вып. 6. 


\section{Literatura}

1. Mil'chik M.I. Drevnerusskaya ikonografiya monastyrey, hramov i gorodov XVI-XVIII vekov: Stat'i 1973-2017 / M.I. Mil'chik. - SPb, 2017.

2. Mil'chik M.I. Severnyy derevyannyy monastyr' na ikonah XVII-XIX vv. / M.I. Mil'chik // Pamyatniki kul'tury. Novye otkrytiya: Ezhegodnik. -L., 1979.

3. Mil'chik M.I. Verkol'skiy monastyr' v ikonografii XVII XVIII vv. / M.I. Mil'chik // Pamyatniki kul'tury. Novye otkrytiya: Ezhegodnik. - L., 1987.

4. Mil'chik M.I. Kargopol'skaya krepost'. Etapy stroitel'noy istorii / M.I Mil'chik., A.B. Bode // Arhitekturnoe nasledstvo. - 2008. -Vyp. 49.

5. RGIA. F. 1350. 0p. 312. D. 3.

6. RGADA. F.192. Novgorodskaya gub. D.8 (Plan NikoloRazvazhskogo monastyrya s okruzhayushhimi dvorami).
7. Mil'chik M.I. Ikonografiya derevyannogo AntonievDymskogo monastyrya i ego graficheskaya rekonstruktsiya / M.I. Mil'chik, E.P. Varakin // Narodnoe zodchestvo: sbornik nauchnyh trudov. - Petrozavodsk, 1992.

8. Shurgin I.N. 0 naruzhnyh rospisyah derevyannyh tserkvey na Russkom Severe v XVII - nachale XVIII v. / I.N. Shurgin // Restavratsiya i issledovanie pamyatnikov kul'tury. - 2014. - Vyp. 7.

9. Demidov S.V. Issledovanie i restavratsiya polihromnoy pokraski nadvratnogo hrama Rozhdestva Ioanna Predtechi v Troitse-Sergievoy lavre/ S.V. Demidov // Restavratsiya i issledovanie pamyatnikov kul'tury. - 2012. - Vyp. 5.

10. Lyubimova I.D. Lopuhinskie palaty moskovskogo Bogoroditse-Smolenskogo Novodevich'ego monastyrya: istoriya i restavratsiya / I.D. Lyubimova // Restavratsiya i issledovanie pamyatnikov kul'tury. - 2013. - Vyp. 6.

Бодэ Андрей Борисович, 1967 г.р. (Москва). Кандидат архитектуры, советник РААСН. Заведующий сектором «Деревянное зодчество» Научно-исследовательского института теории и истории архитектуры и градостроительства (филиал ФГБУ «ЦНИИП Минстроя России») (111024, Москва, ул. Душинская, д. 9. НИИТИАГ), архитектор-реставратор ФГУП ЦНРПМ. Сфера научных интересов: русская деревянная архитектура, традиции, архитектурное формообразование, реставрация деревянных памятников. Автор более 90 публикаций. Тел.: 8 (916) 34132 39. E-mail: bode-niitag@yandex.ru.

Bode Andrei Borisovich, born in 1967 (Moscow). Candidate of Architecture, Advisor of RAACS. Head of the "Wooden Architecture" Sector of the Scientific Research Institute of Theory and History of Architecture and Urban Planning (branch of the Central Institute for Research and Design of the Ministry of Construction, Housing and Utilities of Russia) (111024, Moscow, Dushinskaya st. 9. NIITIAG), architect and restorer of the Federal State Unitary Enterprise TsNRPM. Research interests: Russian wooden architecture, traditions, architectural formation, restoration of wooden monuments. The author of more than 90 publications. Tel.: +7 (916) 341-32-39. E-mail: bode-niitag@yandex.ru. 